\title{
Systemowe uwarunkowania opóźnień w diagnostyce i leczeniu kobiet chorych na raka piersi w Polsce
}

\author{
Sylwia Grodecka-Gazdecka', Piotr Zaborek², Joanna Didkowska ${ }^{3}$, \\ Krystyna de Walden-Gałuszko ${ }^{4}$, Paweł Handschuh ${ }^{5}$, Tadeusz Pieńkowski ${ }^{6}$, \\ Jacek Jassem ${ }^{7}$
}

\begin{abstract}
Wstęp. Wyniki leczenia chorych na raka piersi zależą w dużym stopniu od sprawnego przeprowadzenia procesu diagnostyczno-terapeutycznego. Szczególnie istotny jest czas upływający od początku choroby do rozpoczęcia leczenia. Opóźnienie w podjęciu leczenia może wynikać z przyczyn leżących po stronie pacjenta, lekarza lub systemu opieki zdrowotnej. Celem projektu było określenie przyczyn opóźnień w rozpoznawaniu i leczeniu chorych na raka piersi w Polsce. Poprzednio przedstawiliśmy przyczyny opóźnień wynikające z postaw pacjentek, natomiast w niniejszej pracy omówiono systemowe uwarunkowania opóźnień.

Materiał i metody. Dane uzyskano z ankiety przeprowadzonej w grupie 1000 chorych na raka piersi, leczonych w 10 losowo wybranych polskich ośrodkach onkologicznych i szpitalach z oddziałami onkologicznymi. Czas i strukturę procesu rozpoznawania raka piersi oceniono na podstawie pytań elektronicznego, interaktywnego kwestionariusza. Respondentki zaznaczały, które spośród 6 wydarzeń przypadły im w udziale, oraz określały czas, jaki upłynął pomiędzy poszczególnymi etapami.

Wyniki. Średni czas opóźnienia wynikającego z systemowych uwarunkowań wyniósł 9,0 tygodni. Brak zachorowań na nowotwory w najbliższej rodzinie chorej związany był z wydłużeniem opóźnienia o 2,1 tygodnia. W grupie chorych, które na pierwszą wizytę udały się do onkologa, opóźnienie było krótsze o 1,8 tygodnia w porównaniu z grupą, w której pierwsza wizyta odbyła się u lekarza innej specjalności. Chore w wieku powyżej 59 lat w porównaniu z młodszymi chorymi oczekiwały na rozpoczęcie terapii o 1,5 tygodnia krócej. Średni czas oczekiwania w grupie chorych mieszkających w mieście powyżej 300 tys. mieszkańców był o 1,3 tygodnia krótszy niż w grupie chorych z mniejszych miejscowości. Większa o 1 stopień nieufność w stosunku do systemu ochrony zdrowia i wyników leczenia wpływała na wydłużenie opóźnienia o 0,8 tygodnia. Większy o 1 punkt poziom wsparcia ze strony bliskich związany był z krótszym o 0,6 tygodnia czasem do rozpoczęcia leczenia.
\end{abstract}

\author{
${ }^{1}$ Katedra i Klinika Onkologii \\ Uniwersytet Medyczny im. Karola Marcinkowskiego w Poznaniu \\ ${ }^{2}$ Szkoła Główna Handlowa w Warszawie \\ ${ }^{3}$ Krajowy Rejestr Nowotworów, Zakład Epidemiologii i Prewencji Nowotworów \\ Centrum Onkologii — Instytut w Warszawie \\ ${ }^{4}$ Katedra Psychiatrii, Wydział Nauk Medycznych \\ Uniwersytet Warmińsko-Mazurski \\ ${ }^{5}$ Roche Polska Sp. z o. o., Warszawa \\ ${ }^{6}$ Klinika Onkologii CMKP \\ Europejskie Centrum Zdrowia w Otwocku \\ ${ }^{7}$ Katedra i Klinika Onkologii i Radioterapii \\ Gdański Uniwersytet Medyczny
}

Praca wykonana na podstawie trójstronnej umowy pomiędzy Polskim Towarzystwem Onkologicznym, Polskim Towarzystwem do Badań nad Rakiem Piersi i firmą Roche Polska Sp. z o.o. 
Wnioski. Działania na rzecz zmniejszenia systemowego opóźnienia w rozpoznawaniu i leczeniu chorych na raka piersi w Polsce powinny polegać na usprawnieniu i standaryzacji ścieżek diagnostycznych, zwiększaniu dostępności do badań mieszkankom mniejszych miejscowości, zmniejszaniu nieufności w stosunku do systemu opieki zdrowotnej oraz zwiększaniu kompetencji i roli lekarzy rodzinnych w profilaktyce chorób nowotworowych. Priorytetem powinno być szybkie utworzenie specjalistycznych ośrodków diagnostyczno-leczniczych, zapewniających kompleksową opiekę onkologiczną, ujednolicony sposób rozpoznawania nowotworu i wysoką jakość leczenia.

\section{System-related delays in diagnosis and treatment of breast cancer in Poland}

Introduction. Breast cancer (BC) treatment results depend greatly on prompt and efficient diagnostic and therapeutic decisions. This means that the final treatment outcome is determined by the amount of time elapsed from disease onset to treatment implementation. Delays in implementation may be due to patients, physicians or the healthcare system. The aim of this research project was to identify healthcare system-related causes of delayed diagnosis and treatment of BC in Polish women. In our previous study, we presented causes related to patient attitudes. In this paper causes related to the healthcare system are discussed.

Materials and methods. Data were collected using a questionnaire, completed by $1000 \mathrm{BC}$ patients treated in 10 randomly selected Polish cancer centers and hospitals with oncological wards. The time and structure of BC diagnostic processes were evaluated based on an electronic and interactive questionnaire, where patients selected from the six proposed events that applied to them, and defined the time between specific stages.

Results. The mean delay time due to healthcare system-related causes was 9.0 weeks. If no member of the patient's immediate family had been previously diagnosed with cancer, the delay was prolonged by 2.1 weeks. When the first physician consulted was an oncologist, the delay time was shorter on average by 1.8 weeks, as compared to the patients whose first consulted physician held a different specialization. Patients aged over 59 waited about 1.5 weeks less for treatment than younger women. Treatment duration was 1.3 weeks shorter for patients living in a city of over 300,000 inhabitants, than for those from smaller cities. An increase in mistrust towards the healthcare system and treatment results further extended the delay by 0.8 weeks for each degree of mistrust. Family support shortened the time to treatment implementation by 0.6 week per level of support.

Conclusions. Actions that should be undertaken to reduce delays in $\mathrm{BC}$ diagnosis and treatment in Poland include an increase in efficiency, better standardization of diagnostic pathways, better availability of testing procedures in smaller cities, overcoming the mistrust towards the healthcare system, and increasing the role and competencies of general practitioners in the prophylaxis of neoplastic diseases. Priority should be given to actions which aim to create specialized diagnostic and therapeutic centers, providing comprehensive oncological care, standardized diagnostic procedures and high therapeutic standards.

NOWOTWORY Journal of Oncology 2014; 64, 6: 483-490

Słowa kluczowe: rak piersi, opóźnienie leczenia, uwarunkowania systemowe

Key words: breast cancer, delay in treatment, system related reasons

\section{Wstęp}

Mimo poprawy wyników leczenia chorych na raka piersi w Polsce, opóźnienie procesu diagnostyczno-terapeutycznego i zróżnicowanie czasu jego trwania w poszczególnych ośrodkach jest nadal poważnym problemem. Prognozy epidemiologiczne przewidują dalszy wzrost zachorowalności na raka piersi w Polsce do liczby 21000 nowych zachorowań w 2025 roku. Współczynniki zachorowalności osiągną wówczas poziom $80 / 10^{5}[1]$.

Wpływ opóźnienia rozpoczęcia terapii na wyniki leczenia chorych na raka piersi nie został dotychczas dokładnie określony. Ze względów etycznych niemożliwe jest przeprowadzenie badań klinicznych z losowym doborem chorych. Wie- lokrotnie cytowana publikacja Richardsa i wsp. z 1999 roku, oparta na analizie badań obserwacyjnych obejmujących populację ponad 101000 chorych, podaje, że opóźnienie powyżej 3 i 6 miesięcy obserwowane u odpowiednio $1 / 3$ i 1/4 analizowanej grupy związane było $z$ istotnie gorszym przeżyciem [2]. Zgodnie z zaleceniami Kanadyjskiego Stowarzyszenia Radioterapeutów i Brytyjskiego Towarzystwa Onkologii Klinicznej czas oczekiwania na leczenie nie powinien przekraczać $28 \mathrm{dni}$ [3].

Celem niniejszego projektu było określenie przyczyn opóźnień w rozpoznawaniu i leczeniu kobiet chorych na raka piersi w Polsce. W poprzedniej pracy przedstawiono przyczyny opóźnienia wynikające z postaw chorych [4]. 


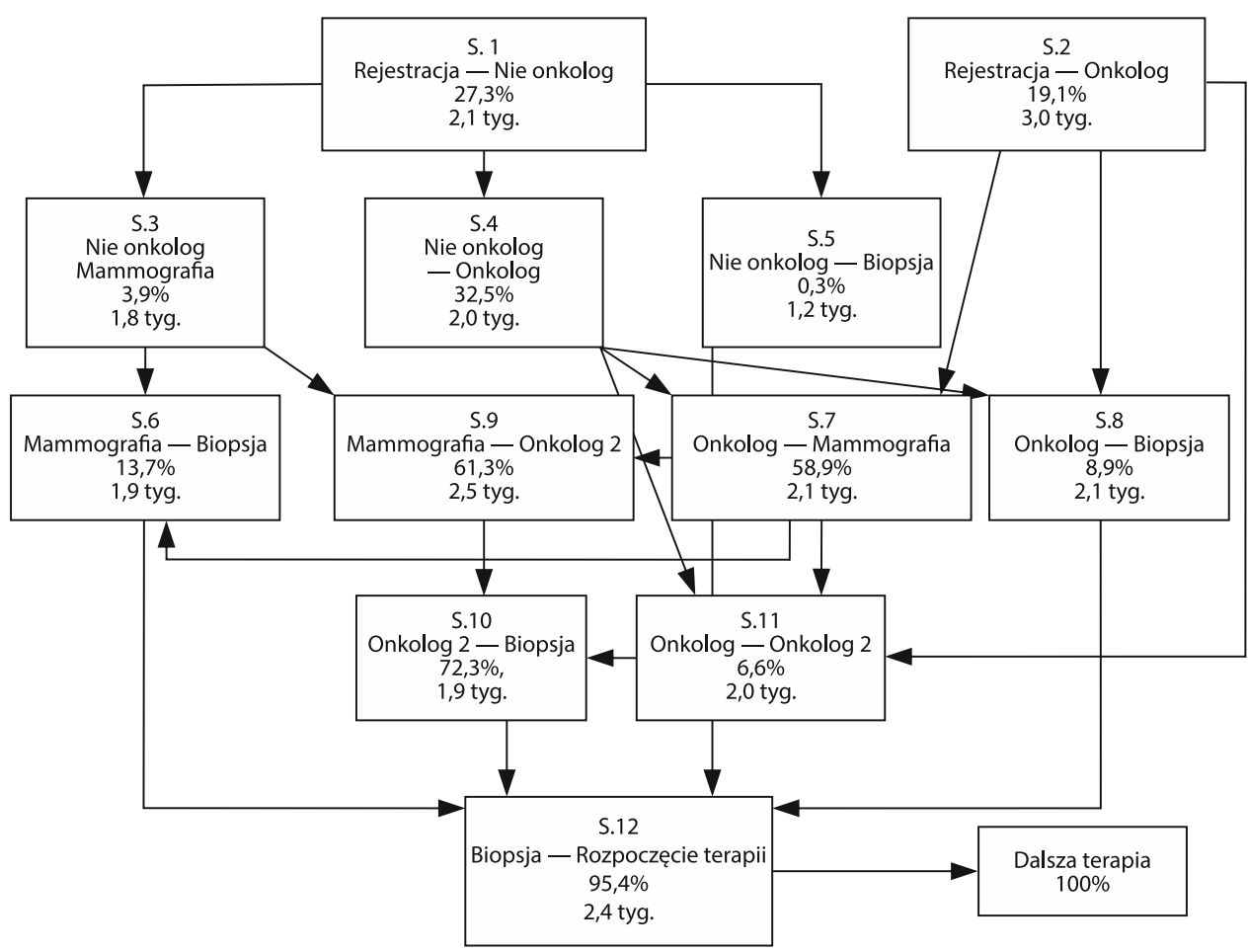

Rycina 1. Ścieżki przebiegu procesu diagnostycznego raka piersi wśród respondentek

W niniejszym doniesieniu omówiono systemowe uwarunkowania opóźnień w rozpoznawaniu i leczeniu chorych na raka piersi w Polsce.

\section{Materiał i metody}

Badanie oparto na wynikach ankiety przeprowadzonej w sierpniu 2011 roku w grupie 1000 chorych na raka piersi, leczonych w 10 ośrodkach onkologicznych i szpitalach z oddziałami onkologicznymi, wybranych losowo zgodnie z zasadami doboru grupowego. Czas i strukturę procesu rozpoznawania raka piersi oceniono na podstawie pytań kwestionariusza, w którym respondentki proszone były o zaznaczenie, które wydarzenia spośród 6 pozycji przypadły im w udziale, oraz określały czas, jaki upłynął pomiędzy poszczególnymi wydarzeniami. W zbieraniu odpowiedzi posługiwano się elektronicznym, interaktywnym kwestionariuszem, udostępnionym badanym kobietom na tablecie, co zapewniło intuicyjne i sprawne pozyskiwanie odpowiedzi.

W procesie diagnostyczno-terapeutycznym wyróżniono następujące wydarzenia:

1. Rejestrację w przychodni lub szpitalu w celu umówienia wizyty u lekarza.

2. Pierwsze badanie przeprowadzone przez lekarza niebędącego onkologiem.

3. Pierwsze badanie przeprowadzone przez onkologa.

4. Mammografię.

5. Drugie badanie przeprowadzone przez onkologa.

6. Biopsję piersi.
7. Rozpoczęcie leczenia (zabieg operacyjny lub leczenie systemowe).

Do pomiaru czasu poszczególnych etapów diagnostycznych wykorzystano zestaw skal składających się z 7 kategorii odpowiadających różnym interwałom czasowym - od okresu krótszego niż 1 tydzień do ponad 12 tygodni.

W celu wyznaczenia średniego czasu trwania całego procesu diagnostycznego czas poszczególnych okresów zamieniono zzapisu skategoryzowanego na tygodnie, przyjmując za przybliżony czas środek zaznaczonego przez chorą przedziału. Następnie zsumowano wartości liczbowe przypisane poszczególnym etapom diagnostycznym. W efekcie otrzymano zmienną opisującą całkowity czas trwania procesu diagnostycznego [5-7].

\section{Wyniki}

Ścieżki przebiegu procesu diagnostycznego przedstawiono na rycinie 1 . Około $2 / 3$ chorych rozpoczęło terapię w ciągu 10 tygodni od momentu rejestracji w placówce ochrony zdrowia. Średni czas trwania diagnostyki wyniósł 9,0 tygodni, z odchyleniem standardowym 6,8 tygodnia.

Przebieg procesu diagnostycznego u poszczególnych chorych był bardzo zróżnicowany i obejmował od 2 do 6 etapów, co pozwoliło wyodrębnić ponad 20 ścieżek diagnostycznych. Końcowym etapem było w każdym wypadku rozpoczęcie leczenia. W wyniku przekształceń wyjściowych zmiennych wyodrębniono 12 różnych etapów diagnostycz- 
Tabela I. Systemowe uwarunkowania opóźnień w rozpoznawaniu i leczeniu chorych na raka piersi

\begin{tabular}{|c|c|c|c|c|}
\hline Cecha & Liczba & Średnia & $\begin{array}{l}\text { Odchylenie } \\
\text { standardowe }\end{array}$ & $\begin{array}{l}\text { 95\% przedział ufności } \\
\text { dla średniej }\end{array}$ \\
\hline \multicolumn{5}{|l|}{ Okoliczności wykrycia objawów raka piersi } \\
\hline Badania okresowe lub wizyta u lekarza z innego powodu & 99 & 7,8 & 5,3 & $6,7-8,8$ \\
\hline Rutynowa lub przypadkowa mammografia & 339 & 9,1 & 6,6 & $8,4-9,8$ \\
\hline Chora sama zauważyła objawy i udała się do lekarza & 562 & 9,1 & 7,2 & $8,5-9,7$ \\
\hline Ogółem & 1000 & 9,0 & 6,8 & $8,6-9,4$ \\
\hline \multicolumn{5}{|l|}{ Ośrodek } \\
\hline A & 271 & 11,6 & 7,6 & $10,7-12,5$ \\
\hline B & 92 & 5,4 & 2,8 & $4,8-5,9$ \\
\hline C & 51 & 11,0 & 6,4 & $9,2-12,8$ \\
\hline D & 129 & 6,6 & 5,2 & $5,7-7,5$ \\
\hline $\mathrm{E}$ & 45 & 11,4 & 9,1 & $8,6-14,1$ \\
\hline $\mathrm{F}$ & 184 & 8,7 & 6,4 & $7,8-9,6$ \\
\hline G & 72 & 7,9 & 5,3 & $6,7-9,2$ \\
\hline $\mathrm{H}$ & 76 & 4,8 & 4,7 & $3,7-5,8$ \\
\hline I & 61 & 11,4 & 7,5 & $9,5-13,3$ \\
\hline J & 19 & 10,2 & 5,1 & $7,7-12,7$ \\
\hline Ogółem & 1000 & 9,0 & 6,8 & $8,6-9,4$ \\
\hline \multicolumn{5}{|l|}{$\begin{array}{l}\text { Specjalizacja lekarza podczas pierwszej wizyty (dotyczy chorych, } \\
\text { które same wykryły podejrzaną zmianę): }\end{array}$} \\
\hline lekarz ogólny/rodzinny & 81 & 9,7 & 7,3 & $8,1-11,3$ \\
\hline ginekolog & 130 & 10,4 & 8,3 & $9,0-11,8$ \\
\hline onkolog & 260 & 8,3 & 6,6 & $7,5-9,1$ \\
\hline internista & 6 & 8,7 & 3,6 & $4,9-12,4$ \\
\hline chirurg & 49 & 9,7 & 6,9 & $7,7-11,7$ \\
\hline inna specjalizacja & 36 & 8,1 & 7,5 & $5,6-10,6$ \\
\hline Ogółem & 562 & 9,1 & 7,2 & $8,5-9,7$ \\
\hline
\end{tabular}

nych. Oprócz nazwy etapu, złożonej z wydarzenia rozpoczynającego i kończącego etap, podane zostały również średnie arytmetyczne czasów trwania etapu (w tygodniach) oraz odsetek chorych, których dany etap dotyczył. Pewne niespójności w sumach procentów spowodowane są potrzebą zachowania przejrzystości i komunikatywności. W tym celu na rycinie pominięto fazy diagnostyczne, które dotyczyły bardzo niewielkiego odsetka badanych kobiet, np. etapy pomiędzy rejestracją i mammografią $(1,6 \%)$, rejestracją i biopsją $(0,1 \%)$, drugim badaniem przez onkologa i rozpoczęciem terapii $(2,4 \%)$ czy mammografią i rozpoczęciem terapii $(0,3 \%)$.

W ocenie skuteczności systemu opieki medycznej uwzględniono następujące czynniki (tab. I).

1. Okoliczności wykrycia objawów raka piersi.

2. Specjalizację lekarza, który postawił rozpoznanie (w grupie 562 chorych, które same wykryły niepokojące objawy i udały się do lekarza w celu postawienia rozpoznania).

3. Ośrodek, w którym chora otrzymywała leczenie.

W odniesieniu do pierwszego z tych czynników chore objęte badaniem podzielono na trzy podgrupy:
1. Chore, u których objawy zostały zauważone w trakcie wizyty u lekarza z innego powodu niż podejrzenie występowania raka piersi (np. podczas okresowego badania ginekologicznego).

2. Chore, u których wykryto objawy raka w wyniku rutynowego lub przypadkowego badania mammograficznego.

3. Chore, które same zauważyły objawy (np. podczas samobadania) i zgłosiły się do lekarza.

Średni czas rozpoznawania w wymienionych 3 podgrupach chorych zawarty był w granicach od 7,8 do 9,1 tygodnia $(p=0,19)$.

Ta sama analiza przeprowadzona w podgrupie chorych, które same zauważyły u siebie objawy raka piersi, wykazała, że czas trwania procesu diagnostycznego zainicjowanego przez onkologa był krótszy niż w przypadku ginekologa lub lekarza ogólnego, ale różnice te również nie były znamienne $(p=0,124)$. Po podzieleniu wszystkich chorych na 2 grupy: tych, które po raz pierwszy zgłosiły się do onkologa, i tych, które zgłosiły się do lekarza innej specjalności, okazało się jednak, że proces ten był w pierwszym przypadku znamiennie krótszy (odpowiednio 8,3 i 9,8 tygodnia; $p=0,019$ ). Czas trwa- 
Tabela II. Czas rozpoznania raka piersi w systemie medycznym (tzw. czas systemowy) w całej grupie chorych

\begin{tabular}{|c|c|c|c|c|c|}
\hline \multirow[t]{2}{*}{ Parametry modelu } & \multicolumn{2}{|c|}{$\begin{array}{c}\text { Współczynniki } \\
\text { niestandaryzowane }\end{array}$} & \multirow{2}{*}{$\begin{array}{c}\begin{array}{c}\text { Współczynniki } \\
\text { standaryzowane }\end{array} \\
\text { Beta }\end{array}$} & \multirow[t]{2}{*}{$t$} & \multirow[t]{2}{*}{ Istotność } \\
\hline & B & Błąd standardowy & & & \\
\hline (Stała) & 7,955 & 0,465 & & 17,104 & 0,000 \\
\hline Czasu opóźnienia z przyczyn po stronie chorej & 0,176 & 0,062 & 0,090 & 2,853 & 0,004 \\
\hline Miejsce zamieszkania: duże miasto (> 300 tys.) & $-1,477$ & 0,440 & $-0,105$ & $-3,358$ & 0,001 \\
\hline Brak zachorowań na nowotwory w najbliższej rodzinie & 1,751 & 0,477 & 0,116 & 3,673 & 0,000 \\
\hline
\end{tabular}

Tabela III. Czas rozpoznania raka piersi w systemie medycznym (tzw. czas systemowy) w grupie chorych, które same zauważyły objawy

\begin{tabular}{|c|c|c|c|c|c|}
\hline \multirow[t]{2}{*}{ Zmienne w modelu } & \multicolumn{2}{|c|}{$\begin{array}{c}\text { Współczynniki } \\
\text { niestandaryzowane }\end{array}$} & \multirow{2}{*}{$\begin{array}{c}\begin{array}{c}\text { Współczynniki } \\
\text { standaryzowane }\end{array} \\
\text { Beta }\end{array}$} & \multirow[t]{2}{*}{ t } & \multirow[t]{2}{*}{ Istotność } \\
\hline & B & Błąd standardowy & & & \\
\hline (Stała) & 5,212 & 1,704 & & 3,060 & 0,002 \\
\hline Zdychotomizowany czas opóźnienia ( $\leq 4$ tyg., > 4 tyg.) & 1,951 & 0,704 & 0,123 & 2,770 & 0,006 \\
\hline Brak zachorowań na nowotwory w najbliższej rodzinie & 2,093 & 0,601 & 0,148 & 3,482 & 0,001 \\
\hline Specjalizacja lekarza (onkolog) & $-1,746$ & 0,613 & $-0,124$ & 2,847 & 0,005 \\
\hline Wiek zdychotomizowany $(\leq 59 ;>59)$ & $-1,538$ & 0,682 & $-0,097$ & $-2,254$ & 0,025 \\
\hline Nieufność & 0,797 & 0,318 & 0,112 & 2,511 & 0,012 \\
\hline Miejsce zamieszkania: duże miasto (> 300 tys.) & $-1,321$ & 0,634 & $-0,091$ & $-2,085$ & 0,038 \\
\hline Wsparcie ze strony bliskich & $-0,637$ & 0,306 & $-0,089$ & $-2,083$ & 0,038 \\
\hline
\end{tabular}

nia procesu diagnostycznego w poszczególnych ośrodkach zawarty był w granicach od 4,7 do 11,6 tygodnia $(p=0,001)$.

Aby wyjaśnić systemowe czynniki wpływające na czas do rozpoczęcia leczenia, skonstruowano dwa modele regresji wielorakiej: obejmujący wszystkie chore (1000 obserwacji), jednak z wyłączeniem chorych, które same odkryły objawy nowotworu, oraz obejmujący 562 chore, które same zauważyły niepokojące zmiany w piersi.

Analiza przeprowadzona w pierwszej $z$ tych grup wykazała, że czas rozpoznania raka piersi związany był z 3 czynnikami odznaczającymi się słabą, ale znamienną współzależnością (tab. Il). Tygodniowemu wzrostowi opóźnienia związanemu z postawami chorych towarzyszyło wydłużenie czasu, spowodowane czynnikami systemowymi, średnio o 0,2 tygodnia. Rozpoznanie w mieście powyżej 300 tys. mieszkańców związane było z czasem krótszym średnio o 1,5 tygodnia, a brak zachorowań na nowotwory wśród kobiet w najbliższej rodzinie - $\mathrm{z}$ dłuższym średnio o 1,8 tygodnia.

W analizie obejmującej 562 chore, które same zauważyły podejrzane zmiany w piersi, liczbę zmiennych powiększono o cechy specyficzne dla tej grupy (tab. III). Czas opóźnienia wynikający z postaw chorych przekraczający 4 tygodnie związany był z dłuższym czasem diagnostyki średnio o 1,9 tygodnia, a z zachorowań na nowotwory w najbliżej rodzinie chorej — skróceniem o 2,1 tygodnia. W przypadku chorych, które pierwszą wizytę odbyły u onkologa, diagno- styka trwała krócej średnio o 1,8 tygodnia, a chore w wieku powyżej 59 lat rozpoczynały leczenie około 1,5 tygodnia wcześniej niż chore młodsze. Większa o 1 stopień nieufność w stosunku do systemu ochrony zdrowia i wyników leczenia związana była z czasem oczekiwania dłuższym o 0,8 tygodnia. Chore zamieszkałe w mieście powyżej 300 tys. mieszkańców czekały krócej na rozpoczęcie leczenia średnio o 1,3 tygodnia, a chore $z$ większym wsparciem ze strony bliskich - o 0,6 tygodnia.

\section{Dyskusja}

Opóźnienie w rozpoczęciu terapii chorych na raka piersi może w istotnym stopniu zmniejszyć jej skuteczność [8]. Przeprowadzone w Wielkiej Brytanii badania sugerują, ze opóźnienie w rozpoznaniu nowotworu może skutkować liczbą 5-10 tys. dodatkowych zgonów [9]. Opóźnienie niezależne od postaw chorych określane jest najczęściej jako czas od pierwszej wizyty u lekarza do podjęcia leczenia. Terminem „przedłużające się opóźnienie” określane jest opóźnienie trwające ponad 6 miesięcy $[2,10]$. Według cytowanego przez Richardsa przeglądu badań wynika, że jeszcze 15 lat temu w Wielkiej Brytanii nawet wśród chorych, które zauważyły niepokojące objawy i zgłosiły się do lekarza rodzinnego w czasie nieprzekraczającym 1 miesiąca i były bezzwłocznie kierowane do ośrodka specjalistycznego, 20-30\% dotyczyło opóźnienie w leczeniu przekraczające 3 miesiące [2]. 
Paradoksem jest to, że czas do podjęcia leczenia wydłuża się także w związku ze stosowaniem zaawansowanych, ale czasochłonnych procedur diagnostycznych. Czas do zabiegu operacyjnego wydłużył się w ciągu ostatnich 10 lat, a jednym z powodów jest coraz większa liczba wykonywanych badań obrazowych. Przykładowo, wykonywanie badania rezonansu magnetycznego piersi w trakcie przedoperacyjnej diagnostyki wydłuża czas do leczenia o 25 dni. Dodatkowym „skutkiem ubocznym" pogłębionej diagnostyki jest zwiększony odsetek amputacji piersi, nieprzekładający się na poprawę wyników. Na ogół uważa się, że opóźnienie operacji do 1 miesiąca nie zmienia wyniku leczenia, ale powoduje niepokój chorych oraz wpływa na ich decyzję o zakresie leczenia operacyjnego [11-13].

Porównanie wyników uzyskanych w poszczególnych krajach jest trudne z uwagi na różne systemy organizacji opieki zdrowotnej. Skrining mammograficzny został wprowadzony w Polsce dopiero w roku 2007. Jak dotychczas, mimo niskiego uczestnictwa, nieprzekraczającego 50\% uprawnionej do badań populacji kobiet, uzyskano pewną poprawę w zakresie obniżenia stopnia zaawansowania nowotworu w momencie rozpoznania [1].

Niniejsza praca dotyczy systemowych uwarunkowań opóźnień w rozpoznaniu i leczeniu chorych na raka piersi w Polsce. Podobnie jak nasza poprzednia praca, dotycząca opóźnień zależnych od postaw chorych [4], jest ona częścią międzynarodowego projektu zrealizowanego równolegle w 12 krajach [14]. Spośród objętych analizą 4816 kobiet u 1946 (40,5\%) proces diagnostyczno-leczniczy zapoczątkowało wykrycie podejrzanej zmiany w piersi w programie przesiewowym lub $w$ trakcie badania lekarskiego. W przedstawionej w pracy populacji polskiej udział ten wyniósł $44 \%$. Wykrycie raka u pozostałych $56 \%$ chorych w wyniku samodzielnego badania potwierdza obserwację, iż w Polsce nadal najwięcej raków piersi rozpoznaje się na podstawie objawów klinicznych, a nie w wyniku badań mammograficznych lub lekarskich [4]. We wspomnianym międzynarodowym projekcie całkowite opóźnienie w leczeniu, stanowiące sumę opóźnienia z przyczyn leżących po stronie chorych i przyczyn systemowych, wahało się w poszczególnych krajach w granicach od 11,5 do 29,4 tygodnia (średnio 14,4 tygodnia), a u 43\% chorych było dłuższe niż 12 tygodni. Dzięki najmniejszemu wśród badanych krajów opóźnieniu wynikającemu z postaw chorych (3,6 tygodnia) całkowite opóźnienie wynosiło w Polsce średnio 11,5 tygodnia i było najkrótsze w analizowanej grupie państw (ale nadal znacznie dłuższe niż postulowane przez towarzystwa naukowe 4-tygodniowe opóźnienie) [3]. Opóźnienie systemowe w Polsce, trwające 9 tygodni, było porównywalne do opóźnienia systemowego na Litwie i w Serbii, a krótsze niż na Słowacji, w Chorwacji, Turcji, Rosji, Bułgarii, na Łotwie, w Rumunii i Indiach. Czynnikami związanymi z mniejszym opóźnieniem z przyczyn systemowych były: rozpoznanie stawiane przez onkologa, posiadanie przynajmniej średniego wykształcenia, wiek > 60 roku życia, choroby nowotworowe w najbliższej rodzinie oraz obecność guza w piersi jako pierwszego objawu choroby [14].

W niniejszym badaniu średni czas poprzedzający leczenie wyniósł 9 tygodni, a 2/3 chorych rozpoczęło leczenie w ciągu 10 tygodni od pierwszego zgłoszenia się do lekarza. Badanie uwidoczniło kilkanaście ścieżek diagnostycznych poprzedzających rozpoczęcie terapii. Może to być wyrazem braku jednolitego, czytelnego sposobu postępowania, który mógłby wpłynąć na skrócenie czasu do rozpoczęcia leczenia. Zasadniczym problemem polskiej onkologii pozostaje niezadowalający udział w mammograficznych badaniach przesiewowych zapraszanych kobiet. Inną przyczyną istnienia wielu ścieżek diagnostycznych mogły być zmieniające się kryteria kwalifikacji do poszczególnych etapów badań przesiewowych w pierwszych latach ich funkcjonowania. W wielu ośrodkach nadal zbyt długi jest czas uzyskania wyników badania przesiewowego. Niejednolity jest sposób kierowania chorych do dalszych etapów diagnostyki — od wskazywania konkretnego ośrodka jako zalecanego do przedstawiania listy wielu ośrodków w regionie, spośród których chora sama wybiera dogodne dla siebie miejsce. Jeżeli w ramach programu przesiewowego wykonana jest biopsja, również czas oczekiwania na jej wynik jest w poszczególnych ośrodkach zróżnicowany.

W roku 2007, w pierwszym roku funkcjonowania Populacyjnego Programu Wczesnego Wykrywania Raka Piersi w Polsce, udział zgłaszających się kobiet wynosił $20 \%$. Choć uczestnictwo to w 2012 roku wzrosło do ok. 50\%, nadal nie spełnia ono zalecanego poziomu 70\%. Różnice w skuteczności funkcjonowania programów przesiewowych w kierunku raka piersi w poszczególnych państwach Unii Europejskiej wynikają z różnej formy organizacji, stosunku liczby placówek udzielających świadczenia do wielkości populacji, która ma zostać objęta badaniami, skuteczności mediów, inicjatyw rządowych i pozarządowych, a także poziomu zaangażowania lekarzy rodzinnych w propagowaniu zasad profilaktyki [15-17].

Świadomy udział w badaniu przesiewowym zależy także od wiedzy na temat jego efektu. Założeniem uchwalonego przez Parlament Europejski w 2003 roku programu kontroli jakości badań przesiewowych było doprowadzenie do zmniejszenia umieralności w Unii Europejskiej z powodu raka piersi o $25 \%$ i zmniejszenia różnic we wskaźnikach przeżycia pomiędzy krajami członkowskimi do 5\% [18]. Badanie opinii publicznej (European Consumer Study 2007) przeprowadzone w 8 krajach Unii Europejskiej (w tym w Polsce) i europejskiej części Rosji wykazało, że aż 92\% ankietowanych kobiet przeceniło rzeczywiste zmniejszenie umieralności, jakie przynosi udział w przesiewowych badaniach mammograficznych. To nadmiernie optymistyczne wyobrażenie nie przełożyło się jednak na masowy udział 
w programach skriningowych. Dodatkowo kobiety w wieku od 50 do 69 lat, do których adresowane są badania przesiewowe, nie były lepiej poinformowane od kobiet spoza tego przedziału wiekowego [19].

Znaczący wpływ na udział w badaniach profilaktycznych ma ich dostępność. Przykładowo, na 18 świadczeniodawców z Wielkopolski, wykonujących badanie mammograficzne w ramach Populacyjnego Programu Wczesnego Wykrywania Raka Piersi, 7 zlokalizowanych jest w Poznaniu, dlatego udział mieszkanek tego miasta jest większy [20]. Problem mniejszej dostępności do badań przesiewowych w małych miejscowościach został częściowo rozwiązany poprzez zapoczątkowanie akcji mobilnych jednostek, tzw. mammobusów. Czynnikami związanymi z rezygnacją z udziału w badaniach przesiewowych są m.in. brak dolegliwości, strach przed badaniem i strach przed niekorzystnym rozpoznaniem oraz brak stacjonarnego ośrodka wykonującego badanie w miejscu zamieszkania. Z kolei najbardziej pożądanymi przez kobiety formami zachęty do udziału w badaniach mammograficznych są imienne zaproszenia, obowiązek poddania się badaniu, przyjazd mammobusu i zaproszenie otrzymane od lekarza POZ. Z danych Systemu Informatycznego Monitorowania Profilaktyki (SIMP) na 2011 rok wynika, że imienne zaproszenie wysyłane pocztą jest skuteczną i jednocześnie tanią formą informowania o bezpłatnym profilaktycznym badaniu mammograficznym, a 68\% kobiet, które poddało się badaniu, dowiedziało się o nim właśnie z takiego zaproszenia. Według danych SIMP na 2012 rok zaproszenia zostały wysłane w każdym województwie do co najmniej 93,5\% uprawnionych do badań przesiewowych.

Przedstawione powyżej niedoskonałości funkcjonowania programów przesiewowych mogły być przyczyną tego, że w niniejszym badaniu kobiety z podejrzaną zmianą wykrytą w trakcie badań mammograficznych nie rozpoczynały leczenia wcześniej niż kobiety, u których nowotwór wykryto innymi metodami. Zgodnie z oczekiwaniami czas potrzebny do rozpoczęcia leczenia był najkrótszy, jeżeli lekarzem inicjującym proces diagnostyczny był onkolog. W diagnostyce raka piersi szczególna rola przypada ginekologom, ich wiedzy i umiejętnościom oraz staranności w badaniu piersi, ponieważ wiele kobiet intuicyjnie postrzega ginekologa jako lekarza pierwszego kontaktu w odniesieniu do objawów ze strony piersi. W Polsce stale zbyt mały jest udział lekarzy rodzinnych w profilaktyce chorób nowotworowych, w tym w zachęcaniu do korzystania z badań przesiewowych, opiece nad chorymi onkologicznymi i udzielaniu psychicznego wsparcia chorym na raka piersi [21]. Dla porównania: w Danii opóźnienie mające przyczynę leżącą po stronie lekarza pierwszego kontaktu (General Practitioner, który nie musi być synonimem lekarza rodzinnego) wynosi 0-2 dni. Nie zmienia to jednak faktu, że całkowite opóźnienie wyniosło w tym badaniu 98 dni, w tym spowodowane postawami chorych średnio 21 dni i z przyczyn systemowych — średnio 55 dni [22].

Do czynników wpływających na opóźnienie w rozpoznaniu i podjęciu leczenia należą także młody wiek chorych (nie objętych programami przesiewowymi) [23-25], czynniki rasowe, etniczne, demograficzne i socjalne (w tym zróżnicowane sposoby finansowania opieki medycznej) [26-33], a nawet typ molekularny raka piersi [34].

Na uwagę zasługuje wydłużenie czasu diagnostyki u pacjentek, które nie miały bezpośrednich doświadczeń choroby nowotworowej w swojej rodzinie. Fakt, że kobiety, które zetknęły się z chorobą nowotworową wśród swoich bliskich, są bardziej skłonne do podjęcia współpracy z lekarzem w zakresie procedur diagnostycznych, jest od dawna dobrze znany [35]. Przyjmuje się, że zachowania zdrowotne pacjentek, w tym zgłaszanie się do lekarza, w dużej mierze zależą od ich tzw. przekonań zdrowotnych [36]. Kobiety, które przeżyły doświadczenie choroby we własnej rodzinie, odczuwają w większym stopniu poczucie zagrożenia możliwością zachorowania niż osoby doświadczeń takich pozbawione. Są także bardziej skłonne dostrzegać powagę tej choroby, jak również bardziej liczą się z nieodwracalnymi skutkami swojej decyzji niezgłoszenia się na czas do lekarza, a zarazem są bardziej świadome pozytywnych skutków podjęcia w porę diagnostyki i leczenia [37].

Niepokojące są wykazane w niniejszym badaniu duże różnice pomiędzy ośrodkami, z których pochodziły respondentki (dwukrotna pomiędzy ośrodkiem o najkrótszym i najdłuższym czasie oczekiwania). Chociaż ankietowy charakter badania nie pozwala na zmierzenie parametrów związanych z charakterystyką poszczególnych placówek, to konsekwencją tego zróżnicowania mogą być istotne różnice w wynikach leczenia chorych na raka piersi w Polsce [38]. Wskazuje to równocześnie na możliwość poprawy wyników leczenia chorych na raka piersi poprzez lepszą koordynację procesu diagnostyczno-leczniczego. Cel ten można byłoby osiągnąć m. in. poprzez utworzenie w Polsce sieci wielospecjalistycznych ośrodków na wzór zespołów ds. leczenia chorych na raka piersi (breast cancer units), stwarzających optymalne warunki jego rozpoznawania i leczenia.

Podsumowując, działania na rzecz zmniejszenia systemowego opóźnienia w rozpoznawaniu i leczeniu chorych na raka piersi w Polsce powinny polegać na usprawnieniu i standaryzacji ścieżek diagnostycznych, zwiększeniu dostępności do badań mieszkankom mniejszych aglomeracji, zmniejszeniu nieufności w stosunku do systemu opieki zdrowotnej oraz zwiększeniu kompetencji i roli lekarzy rodzinnych w profilaktyce chorób nowotworowych. Priorytetem powinny być szybkie działania prowadzące do powstania specjalistycznych ośrodków diagnostyczno-leczniczych, zapewniających kompleksową opiekę onkologiczną, ujednolicony sposób rozpoznawania nowotworu i wysoką jakość leczenia. 


\section{Podziękowania}

Dziękujemy dyrektorom następujących instytucji (w kolejności alfabetycznej miast) za umożliwienie przeprowadzenia badania ankietowego, będącego podstawą niniejszego opracowania: Centrum Onkologii im. Franciszka Łukaszczyka w Bydgoszczy, Wojewódzki Szpital Specjalistyczny im. NMP w Częstochowie, Wojewódzkie Centrum Onkologii w Gdańsku, Centrum Onkologii Ziemi Lubelskiej im. Św. Jana z Dukli w Lublinie, Wojewódzki Szpital Specjalistyczny im. Mikołaja Kopernika w Łodzi, Szpital Kliniczny Przemienienia Pańskiego UM w Poznaniu, Szpital Wojewódzki Św. Łukasza w Tarnowie, Centrum Onkologii — Instytut im. Marii Skłodowskiej-Curie w Warszawie, Klinika Onkologiczna przy ul. Wawelskiej, Centrum Onkologii — Instytut im. Marii Skłodowskiej-Curie w Warszawie, Dolnośląskie Centrum Onkologii we Wrocławiu.

Redakcję i pomoc techniczną w przygotowaniu tekstu zapewniła agencja Proper Medical Writing Sp. z o.o., Warszawa.

\section{Konflikt interesu: nie zgłoszono}

Prof. dr hab. n. med. Sylwia Grodecka-Gazdecka Katedra i Klinika Onkologii Uniwersytet Medyczny im. Karola Marcinkowskiego ul. Szamarzewskiego 82/84, 60-569 Poznań

e-mail:sylwia.grodecka-gazdecka@skpp.edu.pl

\section{Przyjęto do druku: 3 września 2014 r.}

\section{Piśmiennictwo}

1. Didkowska J, Wojciechowska U. Nowotwory piersi w Polsce i Europie _ populacyjny punkt widzenia. Nowotwory J Oncol 2013; 63: 111-118.

2. Richards MA, Westcombe AM, Love SB i wsp. Influence of delay on survival in patients with breast cancer: a systematic review. Lancet 1999; 353: 1119-1126.

3. Maślach D, Krzyżak M, Szpak A i wsp. Waiting time for treatment of women with breast cancer in Podlaskie Voivodeship (Poland) in view of place of residence. A population study. Ann Agric Environ Med 2013; 20: 161-166.

4. Grodecka-Gazdecka S, Zaborek P, Didkowska J, de Walden-Gałuszko K, Handschuh $\mathrm{P}$, Jassem J, Pieńkowski T. Uwarunkowanie opóźnień w diagnostyce i leczeniu raka piersi w Polsce związane z postawami chorych. Nowotwory J Oncol 2014; 64: 135-142.

5. Fisher LD, van Belle G, Heagerty PJ, LumleyT. Biostatistics: AMethodology for the Health Sciences. Wyd. 2 Hiboken, New Jersey, John Willey \& Sons; 2004.

6. Armitage P, Berry G, Matthews JNS. Statistical Methods in Medical Research. Wyd. 4, Malden, Massachusetts: Blackwell; 2002.

7. Leech NL, Barrett KC, George AM. SPSS for Intermediate Statistics: Use and Interpretation. Wyd. 2, Mahwah, New Jersey, Lawrence Erlbaum Associates, Inc.; 2005

8. O'Mahoney M, Hegarty J. Factors influencing women in seeking help from a health care professional on self discovery of a breast symptom, in an Irish context. J Clin Nursing 2009; 18: 2020-2029.

9. Richards MA. The National Awareness and Early Diagnosis Initiative in England: assembling the evidence. BrJ Cancer 2009; 101 Suppl 2: S1-4.

10. Burgess CC, Hunter MS, Ramirez AJ. A qualitative study of delay among women reporting symptoms of breast cancer. Br J Gen Pract 2001; 51: 967-971.

11. Hulvat M, Sandalov N, Rademaker A i wsp. Time for diagnosis to definitive operative treatment of operable breast cancer in the era of multimodal imaging. Surgery 2010; 148: 746-750.
12. Montella M, Crispo A, D'Ainto G i wsp. Determinant factors for diagnostic delay in operable breast cancer patients. Eur J CancerPrev 2001; 10:53-59.

13. Bleicher RJ, Ruth K, Sigurdson ER i wsp. Preoperative delays in the US Medicare population with breast cancer. J Clin Oncol 2012; 30: 4485-4492.

14. Jassem J, Ozmen V, Bacanu F i wsp. Delays in diagnosis and treatment of breast cancer: a multinational analysis. Eur J Public Health 2013; Sep. 12 [Epub ahead of print].

15. Giordano L, von Karsa L, Tomatis M i wsp. Mammographic screening programmes in Europe: organization, coverage and participation. JMed Screen 2012; 19 Supl 1: 72-82.

16. Haukka J, Byrnes G, Boniol M i wsp. Trends in breast cancer mortality in sweden before and after implementation of mammography screening. PLoS One 2011; 6: e22422.

17. Heisey R, Clemons M, Granek Li i wsp. Health care strategies to promote earlier presentation of symptomatic breast cancer: perspectives of women and family physicians. Curr Oncol 2011; 18: e227-e237.

18. Perry N, Broeders M, de Wolf C i wsp. Europejskie zalecenia dotyczące jakości badań przesiewowych i rozpoznawania raka piersi. Czwarta edycja - streszczenie dokumentu. Onkol Prakt Klin 2008; 4: 74-86.

19. Gigerenzer G, Mata J, Frank R. Public knowledge of benefits of breast and prostate cancer screening in Europe. J Natl Cancer Inst 2009; 101: 1216-1220.

20. Dyzmann-Sroka A, Bagniewska K, Chyła K i wsp. Dlaczego Wielkopolanki nie robią badań mammograficznych? - raport. Zesz. Nauk. WCO 2012; 9: 169-181.

21. Gazdecka-Szpecht K. Rola lekarza rodzinnego w profilaktyce wybranych nowotworów złośliwych. Praca doktorska. Poznań, 2013.

22. Hansen RP, Vedsted $P$, Sokolowski l i wsp. Time intervals from first symptom to treatment of cancer: a cohort study of 2,212 newly diagnosed cancer patients. BMC Health Services Research 2011; 11: 284-291.

23. Smith EC, Ziogas A, Anton-Culver H. Delay in surgical treatment and survival after breast cancer diagnosis in young women by race/ethnicity. JAMA Surg. 2013; 148: 516-523.

24. Partridge $\mathrm{AH}$, Hughes $\mathrm{ME}$, Ottesen RA i wsp. The effect of age on delay in diagnosis and stage of breast cancer. Oncologist 2012; 17: 775-782.

25. Ruddy KJ, Gelber S, Tamimi RM i wsp. Breast cancer presentation and diagnostic delays in young women. Cancer 2014; 120: 20-25.

26. Trufelli DC, Miranda Vda C, Santos MB i wsp. Analysis of delays in diagnosis and treatment of breast cancer patients at a public hospital. Rev Assoc Med Bras 2008; 54: 72-76.

27. Poum A, Promthet S, Duffy SW I wsp. Factors associated with delayed diagnosis of breast cancer in northeast Thailand. JEpidemiol 2014; 24: 102-108.

28. Williams DL, Tortus S, Thomson J. Factors associated with delays of diagnosis and treatment of breast cancer in women in a Louisiana urban safets net hospital. Women Health 2010; 50: 705-718.

29. Stuver SO, Zhu J, Simchowitz B i wsp. Identifying women at risk of delayed breast cancer diagnosis. Jt Comm J Qual Patient Saf 2011; 37: 568-575.

30. Pruitt SL, Shim M, Mullen PD i wsp. Association of area socioeconomic status and breast, cervical and colorectal cancer screening: a systemic review. Cancer Epidemiol Biomarkers Prev 2009; 18: 2579-2599.

31. Reeler A, Qiao Y, Dare L i wsp. Women's cancers in developing countries: from research to an integrated health systems approach. Asian Pac J Cancer Prev 2009; 10: 519-526.

32. Unger-Saldana K, Pelaez-Ballestas I, Infante-Castaneda C. Development and validation of a questionnaire to assess delay in treatment for breast cancer. BMC Cancer 2012; 12: 626.

33. McGee SA, Durham DD, Tse CK i wsp. Determinants of breast cancer treatment delay differ for African American and White women. Cancer Epidemiol Biomarkers Prev 2013; 22: 1227-1238.

34. Eastman A, Tammaro Y, Moldrem A i wsp. Outcomes of delays in time to treatment in triple negative breast cancer. Ann Surg Oncol 2013 20: 1880-1885.

35. Vernon SW, Vogel V, Halabi S i wsp. Factors associated with perceived risk of breast cancer among women attending a screening program. Breast Cancer Rest.Treat 1993, 28, 137-144.

36. Paskett ED, McLaughlin JM. Breast Cancer Screening. W: Holland J i wsp. (red.) Psycho-oncology. Oxford University Press Oxford 2010, 90-97.

37. Bobo JK, Lee NC, Thames SF. Findings from 752,081 clinical breast examinations reported to a national screening program from 1995 thorough 1998. J Natl. Cancer Int. 2000, 92, 971-976.

38. Kozierkiewicz A, Topór-Mądry R, Śliwczyński A i wsp. Skuteczność i koszty leczenia raka piersi w Polsce; podejście regionalne. Nowotwory J Oncol 2014; 64: 24-32. 